\title{
THE LORE AND LURE OF RHINE GOLD
}

\author{
David J. Mossman \\ Dept. of Physics, Engineering or Geology \\ Mount Allison University \\ Canada
}

Denis Leypold

Musée de Minéralogie

Université Louis Pasteur

France

Gold in its various forms, natural and otherwise, has been in the service of mankind since the dawn of humanity. The lure of gold lies at the root of many myths and legends that have arisen throughout the ages.

This article contrasts the Rhine gold legend with the realities of winning alluvial gold from the river. 


\section{The Rhine gold legend is} recounted in an epic poem of some 4000 strophes that emerged in the 13 th century but which certainly owes much to older sagas. Richard Wagner adapted the story to a four part opera named 'The Ring of the Nibelungs' with which the Beyreuth theatre was inaugurated in 1876. The four parts are: Rhine Gold, The Valkyries, Siegfried and Twilight of the Gods. According to the legend, the Rhine gold was guarded by Rhine maidens. As long as the gold stayed at the bottom of the river all was well with the world. Alas, the evil dwarf Alberich succeeds in stealing the gold and with the help of his fellows in the dark underground kingdom of the Nibelungs, he promptly forges a ring of power. Then Wotan, head of the gods, takes a hand, recovers the ring as well as the rest of the gold and pays the two giants Fafner and Fasolt to build Valhalla, a home for the gods. The giants quarrel and Fafner kills Fasolt and changes himself into a dragon so as to better guard the treasure.

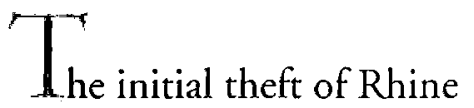
gold throws the universe into an uproar and the task of restoring the gold to the Rhine falls to Siegmund and his son Siegfried. The process is not only embarrassing to the gods, but eventually causes the disappearance of their dwelling place Valhalla.

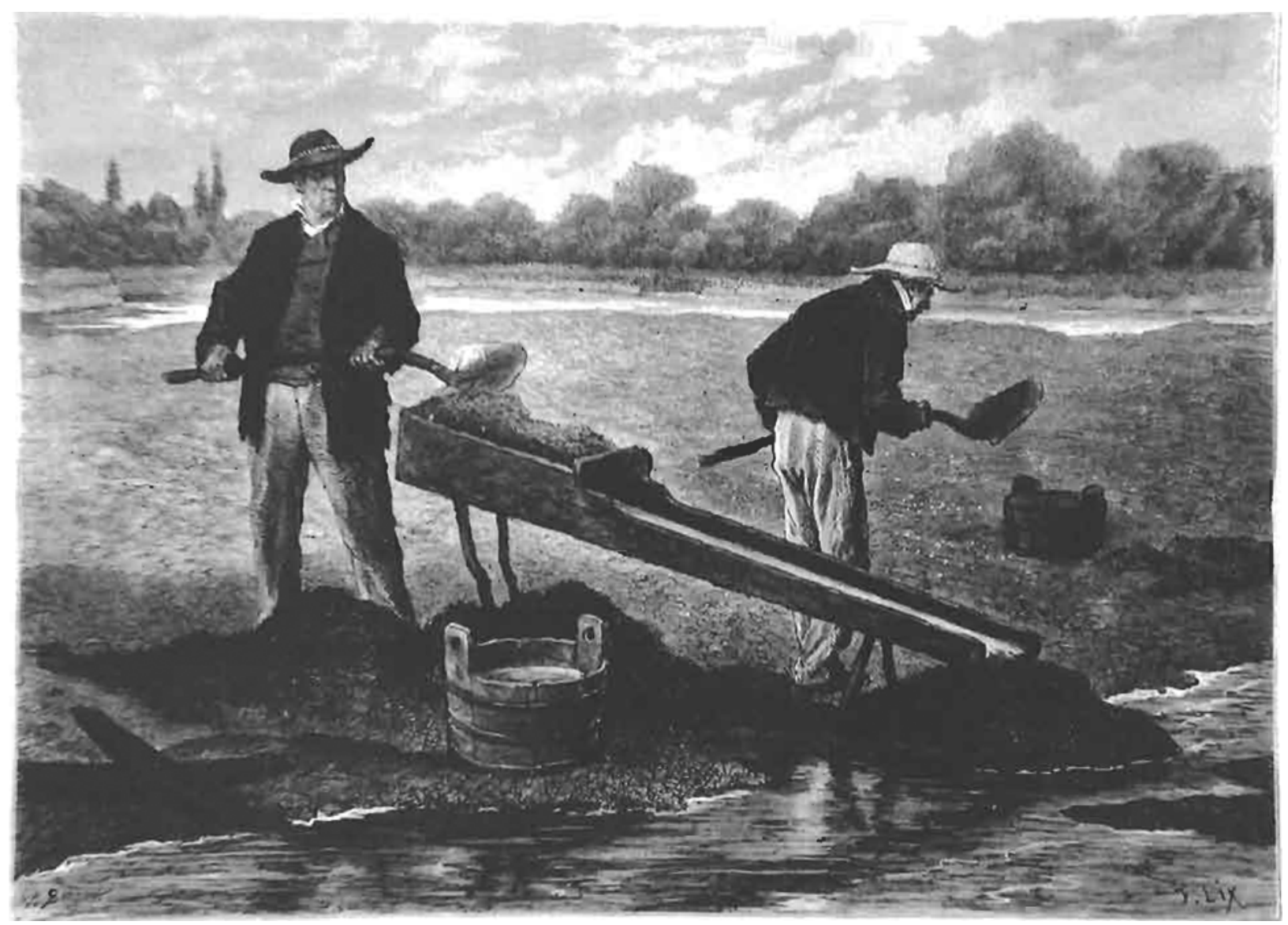

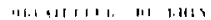

'Orpailleurs du Rhin' - Gold panners on the Rhine; illustration (coloured) published by Charles Grad (1889, p. 277) of a wood carving by Frederic Lix 
Auriferous white quartz pebble found in 1847 in alluvial workings in the River Ill (a Rhine tributary) in front of the old Customs Building, Strasbourg. Pebble measures $6.6 \times 4.7 \times 3 \mathrm{~cm}$. Photo by Constant Schohn, Editions du Jardin des Sciences, Université Louis Pasteur, Musée Minéralogique, Strasbourg

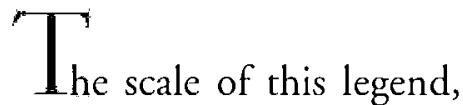
and the impact it has had on Europe and the world is tremendous. For example, Hitler was so infatuated with Wagnerian opera that the heroes of German mythology were, for him, real. It is enough to cause one to almost forget the reality of gold in the sands and gravels of the Rhine. But the yellow metal is most definitely present. For the most part, it occurs as minute flakes or colours seldom exceeding $1 \mathrm{~mm}$ in diameter, as examination of any heavy mineral concentrate will reveal.

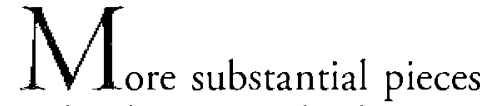
of Rhine gold are exceedingly rare. Indeed, Strasbourg boasts the single known nugget, or rather quartz pebble, containing Rhine gold that survived recovery in 1847 in Strasbourg from allu-

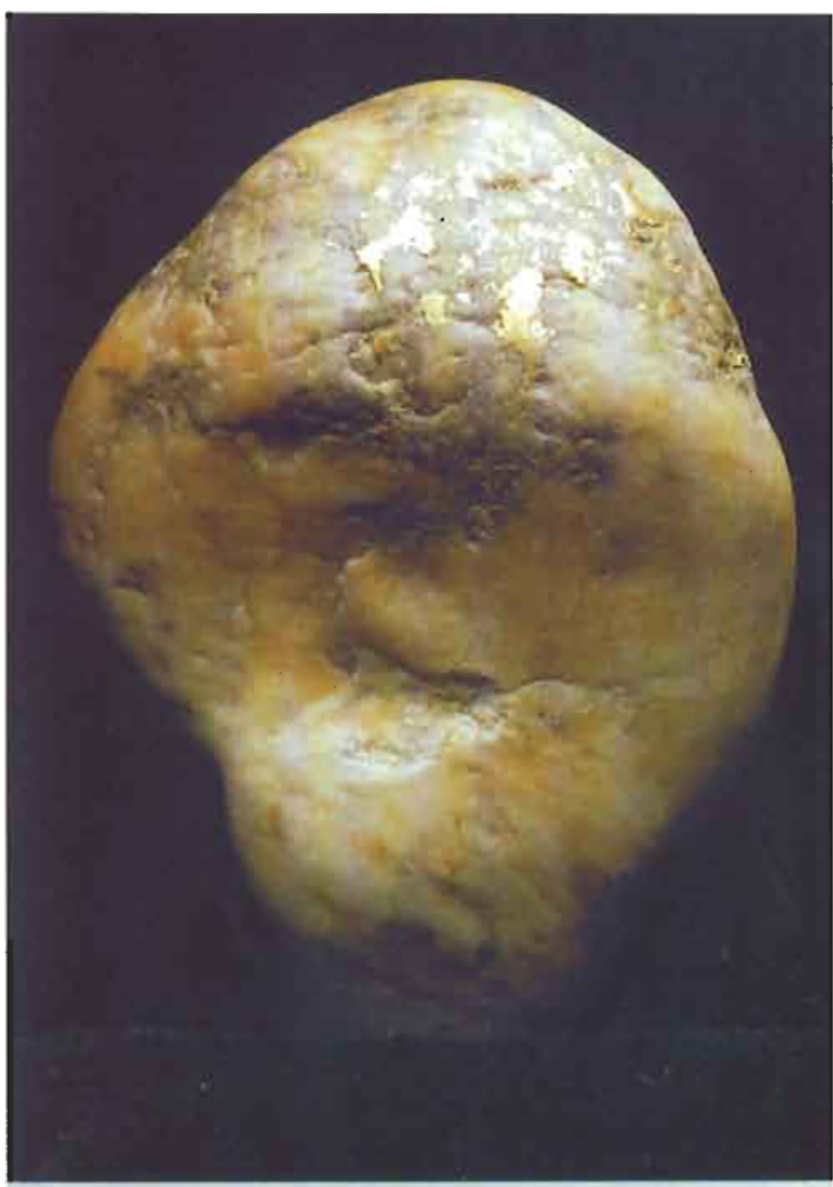

vial workings in the Ill River, a Rhine tributary. This was just before extensive canalization of the river was undertaken.

Flakes of Rhinegold in heavy mineral concentrate from the Rhine (Magneteisensand, Rheinufer). Sample in Musée Minéralogique, University of Strasbourg. Flakes of gold are $<0.5 \mathrm{~mm}$ diameter (Photo DJM)

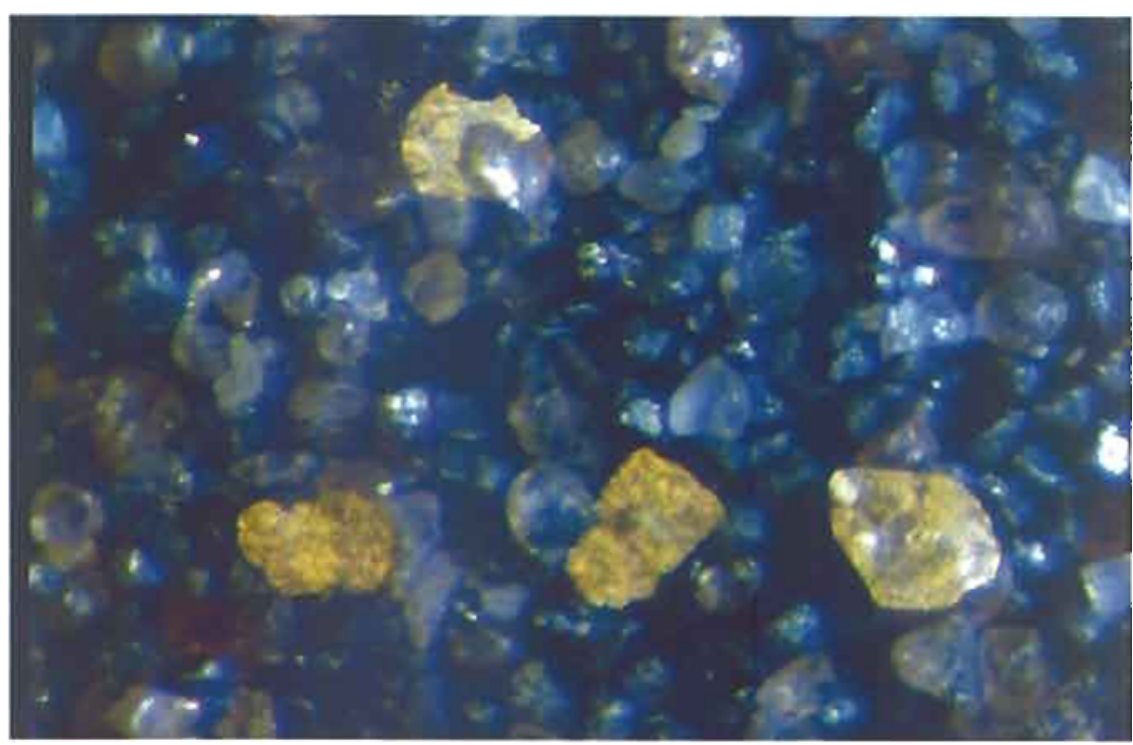




\section{The ancient Gauls are} known to have recovered alluvial gold, and there is little doubt that the Rhine was one of the sources. As early as 667 AD (Grandidier, 1776), records show that the Duke of Alsace, Ethicon, distributed the rights to wash for gold along the Rhine. Production continued throughout the Middle Ages up until the discovery of America, after which time imports from the New World greatly depreciated the value of laboriously won Rhine gold.

\section{Small scale commercial} workings increased during the period 1750 1850 , principally along about $250 \mathrm{~km}$ of river from Basel, Switzerland, to Mannheim, Germany. A good year's workings yielded as much as $15 \mathrm{~kg}$ of gold (Lieber, 1982). Overall, about $500 \mathrm{~kg}$ were recovered from 'Le Pays de Bade et l'Alsace' near Baden-Baden, Mannheim and Karlsruhe. The great French chemist Daubrée in 1852 recorded 1 gram of gold/metric tonne of sand as typical of the richer gravel beds. These beds occupied typically 200 to $300 \mathrm{~m}^{2}$ and seldom exceeded $15 \mathrm{~cm}$ in thickness. 'This 'ore', at $1 \mathrm{ppm}$ gold, is a marginal concentration indeed for any but the largest of modern gold mining enterprises. According to Daubrée's analysis Rhine

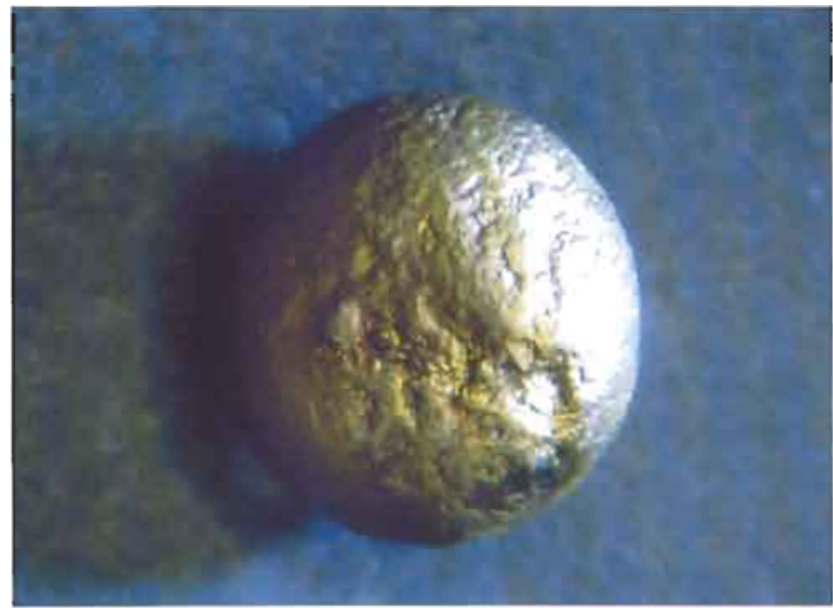

gold contains the precious metals $\mathrm{Au}, \mathrm{Ag}$ and $\mathrm{Pt}$ in the proportions 0.934 to 0.066 to 0.00069 .

\section{It was long thought that} the source of Rhine gold is quartz veins in quartzites and amphibolite schists high in the Swiss alps. Doubtless, at some earlier geological age some of it did thus qualify as having once been Swiss gold. However, at least some of it originates in the lower Rhine or Bas-Rhin area of France, specifically in the Münster Valley where it was discovered in 1987 by the prospector Alphonse Taesch. The manner of discovery would probably not qualify as the stuff of legends, resulting as it did (in the prospector's words) from perseverance and thanklessness, and from hard work sustained over a period of years. The region in question is one of granite bedrock, where gold traditionally was considered non-existent. More than this the discoverers will not confide. At present, exploratory diamond drilling is being conducted on the Münster property, behind a veil of secrecy in order to guard against claim jumpers and general banditry. According to a newspaper report, electron microprobe analysis of Münster gold matches exactly the ancient analysis of Rhine gold at $96 \% \mathrm{Au}$ $4 \% \mathrm{Ag}$. Fire assay of a $5 \mathrm{~kg}$ sample of auriferous quartz yielded $25 \mathrm{~g} / \mathrm{t}$.

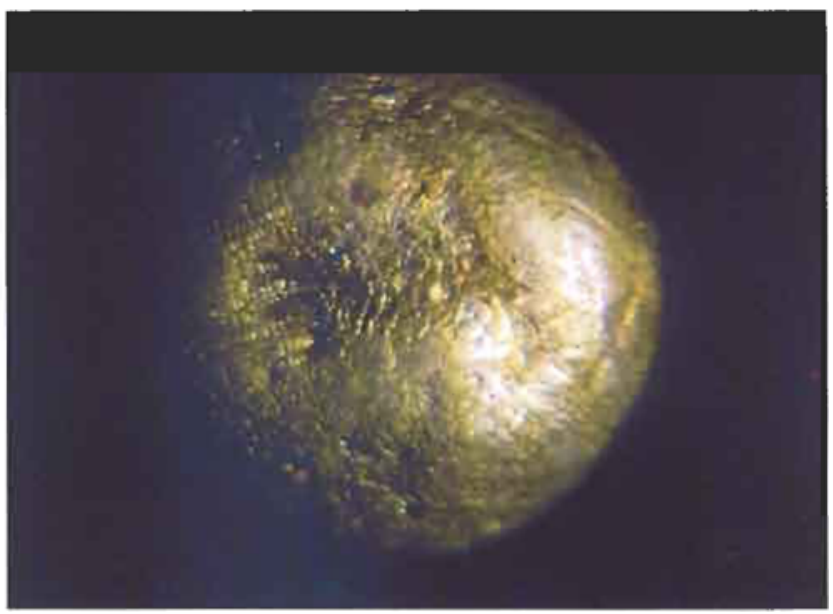

Droplets of Rhine gold smelted at Goldscheuer, near Kehl, Baden. Attached to the tiny protuberance on the smaller droplet is a portion of oxidized siliceous melt. Diameters of the droplets are 0.6 and $0.4 \mathrm{~cm}$ (Photo by DL) 


$$
\text { Examination of several }
$$

modest samples of Rhine gold, displayed in the Musée de Minéralogie, Université Louis Pasteur, confirms the reality of a local source for at least some of the gold recovered from alluvial workings in the Bas-Rhin. All are such fragile samples of crystalline gold that it seems unlikely that they could survive transport from the Alps. Nor is it probable that they represent growth of gold in situ within the alluvium. It thus seems certain that Rhine gold originates from two or more different regions.

\begin{abstract}
Although nothing remains of the old gold workings, two tiny droplets of Rhine gold smelted at Goldscheuer near Kehl, Baden, still exist and are part of the display in the mineralogical museum. Preserved on the surface of each droplet is a microcrystalline, rectilinear, cell-like pattern inherited from the smelting process. Most telling and precious testimony to the power once attributed to Rhine gold is found in treasured surviving ducats, minted during times when emperors, kings and demi-gods still reigned supreme. The older coin,
\end{abstract}

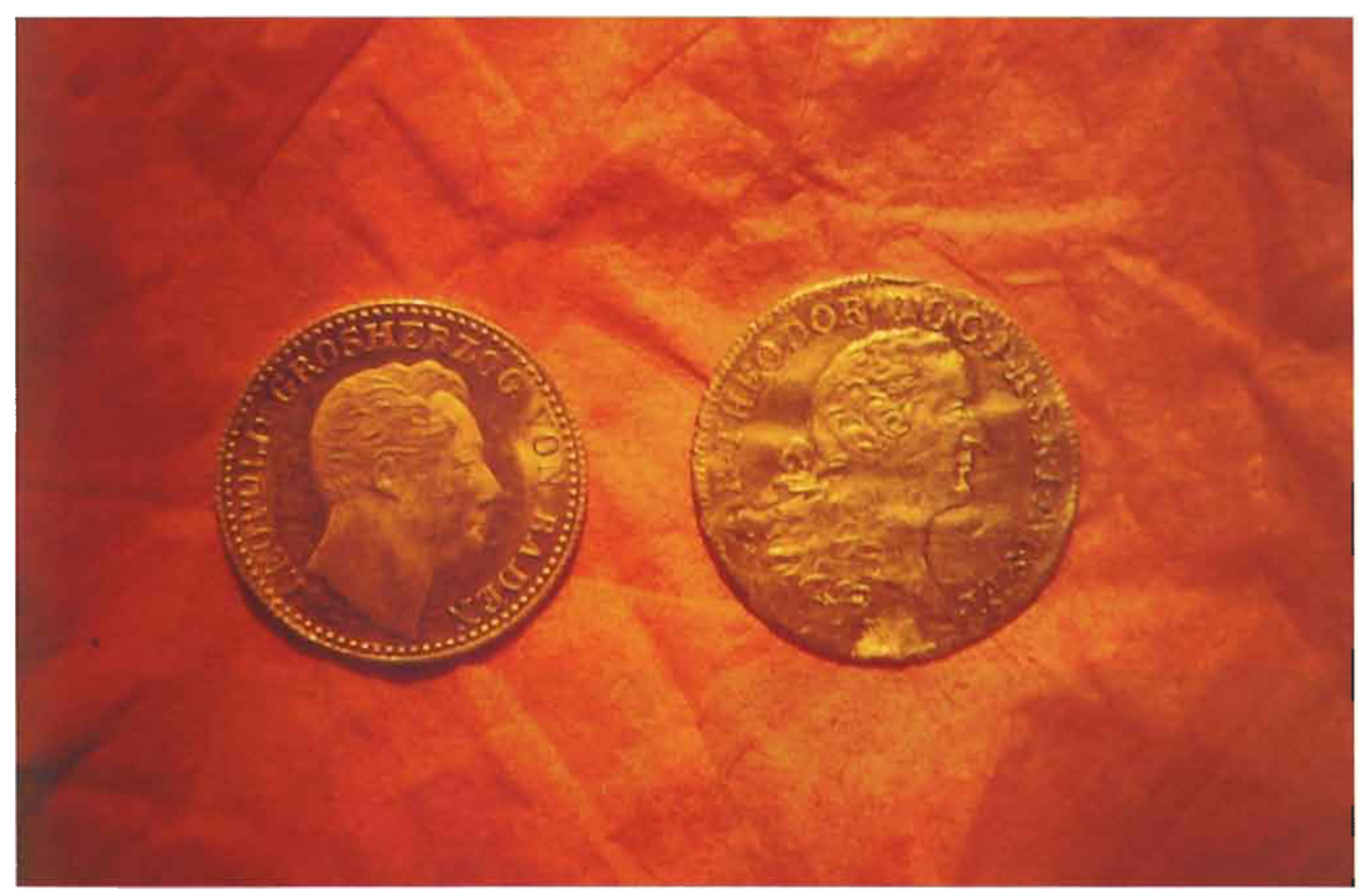

Two ducats of gold. The smaller ducat (left hand side of the photograph) is $20 \mathrm{~mm}$ in diameter, $0.8 \mathrm{~mm}$ thick, weighs $3.7 \mathrm{~g}$, and is dated 1850. It shows grand duke Leopold Grosherzog von Baden. Reverse side: 'Ein Ducat aus Rheingold zu 22 K GG 1850': This ducat carries the number 920 in the numismatic catalogue published by Wielandt (1979).

The larger ducat (right hand side of the photograph) has a diameter of 21.3 to $21.5 \mathrm{~mm}$, thickness $0.7 \mathrm{~mm}$, weight $3.5 \mathrm{~g}$, and is dated 1767. It shows Car. Theodor D. G. C. P. R. S. R. I. A. T. E., which translates as Dei Gratia Comes Palatinus Rheni Sacri Romani Imperii Archidapifer Tutor \& Elector. Reverse side has the motto 'Sic fulgent littora Rheni' (Thus shine the shores of the Rhine) and shows miners working in the alluvium beside the residential castle of the count of the Palatinate. This is a very rare coin 


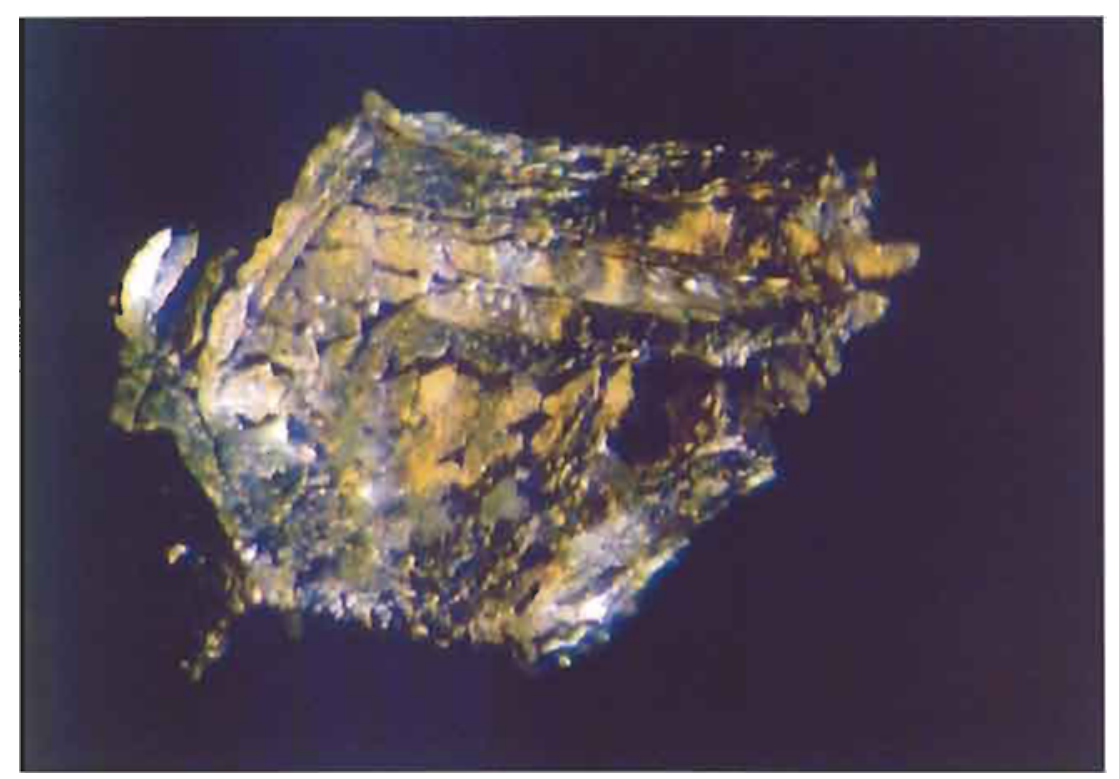

Crystalline gold recovered from alluvial workings: 'Paillete cristallisée'. Tiny intergrown sheets of gold. Specimen measures $3 \mathrm{~mm}$ in length (Photo by $\mathrm{DL}$ )

minted in 1767 shows Car. Theodor, Count of the Palatinate region. The reverse side of this coin shows gold miners working in the river bed beneath the Rhine Bridge, a major thoroughfare that facilitated intense traffic between the Rhine Valley (Bourgogne) and German towns in Lorraine. In the background the sun casts her rays upon the Chateau, a baroque construction dating from the early part of the 18 th century. This served as the Count's official residence (Kurpfalz) in Mannheim, Germany. The smaller ducat dates from 1850 and bears the head of Leopold Groß- herzog von Baden. The reverse side bears a shield surrounded by a laurel wreath and topped with a crown.

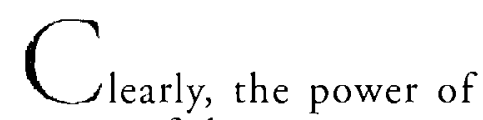
gold, like that of the image of the reigning nobility, was intended to be projected and preserved. The power of Rhine gold endures. The images alone remain of the nobility. Their positions of power are no more. To judge from the

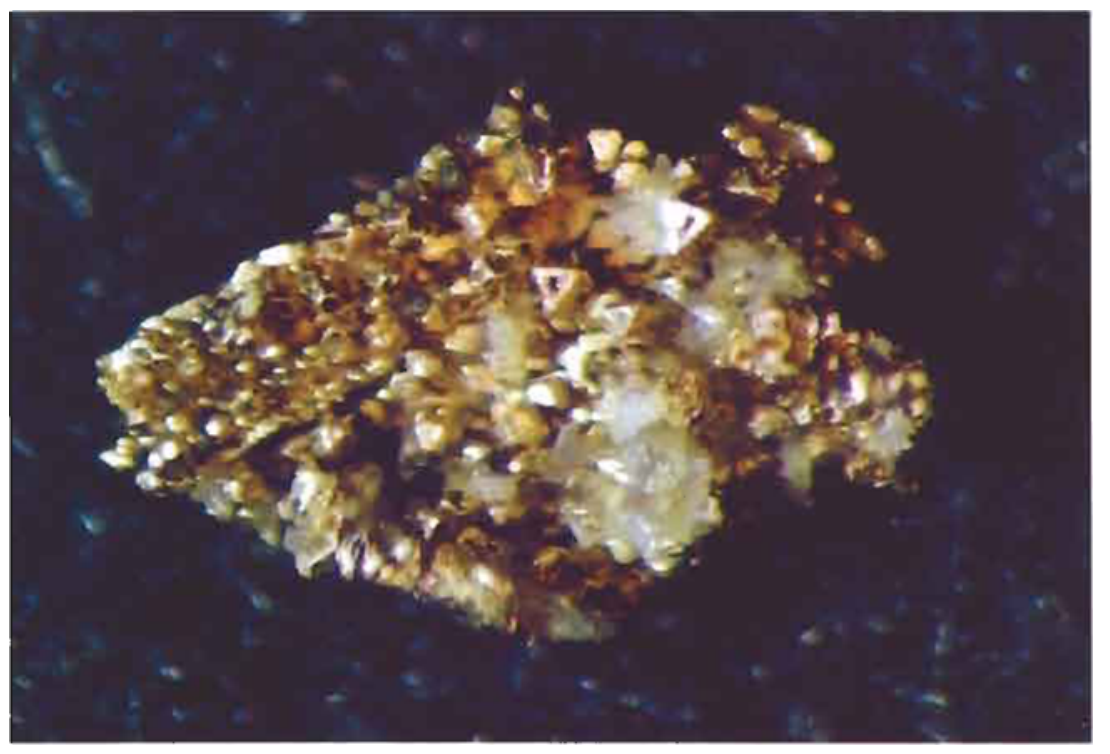

Crystalline gold recovered from alluvial workings. 'Or natif, pailleté avec fer, titane et sable du Rhin'. Brilliant sharp octahedral crystals of gold, a few of which show pseudohexagonal habit, are intimately intergrown with tiny quartz crystals less than $0.1 \mathrm{~mm}$ in diameter (Photo by $D L$ ) 
troubled history of the Alsace region, the world in those times was indeed in an uproar of wars and rumors of wars. Thus, to a considerable degree, mythology has been reenacted in fact. Alas, this poor old battered world seems condemned to perpetual turmoil.

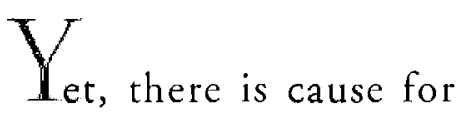

some celebration. Daubrée, great scientist that he was, saw through to the truth of the matter. He performed a modest calculation of the amount of Rhine gold left untouched in the gravel deposits along an approximately $125 \mathrm{~km}$ stretch of the Rhine between Rheinau and Philipsbourg, on the vast plain harrowed by Rhine waters throughout millennia. The amount totals $35 \mathrm{t}$, at least an order of magnitude more than all of the Rhine gold thus far mined. Most assuredly the estimate is a minimum. This fact ought at least help pacify the gods to some degree for past injustices.

\section{References}

A. Daubrée, 1852, 'Description Géologique et Minéralogique du Département du Bas-Rhin', Strasbourg, 1852, L. $\mathrm{J}$. à la lithographie de E. Simon, Rue du Dome 8, Strasbourg, p. 735-740

H. Ungemach, 1936, 'Minéraux de l'Alsace'. Bull. Ass, Philomat. A.-L., v. 8 , p. $227-245$

A. Daubrée, 1845, 'Mémoire sur la distribution de l'or dans la plaine du Rhin et sur l'extraction de ce métal'. Ann. min. (4) X, p. 3-36 and Bull. géol. Fr., (2) III, 1845, p. 458-65. C. R. Ac. Sc., 1845, p. 639-641. L. J., 1848, p. 233

Ph.-Fr. Dietrich, 'Description gites de minerais, forges, salines, verreries, etc. de la Haute et Basse-Alsace', Paris, Descr. des gites de min. etc. de la France, tome II. 1789 C. Grad, 1889, 'L'Alsace et ses Habitants', Hachette, Paris P.A. Grandidier, (Abbé), 1776, 'Histoire de l'Eglise de Strasbourg - I', Argentor, p. 367. (Ethicon, duc d'Alsace, accorde le droit de lavage de l'or du Rhin à titre de donation à un monastère, charte de 667)

Kachel, 1838, 'Über das Vorkommen des Rheingoldes zwischen Kehl und Daxlanden bei Karlsruhe', Badisches Landwirtschafliches Wochenblatt, p. 181)

Lieber, W., 1982, 'Europen gold', The Mineralogical Record v. 13 (6), p. 359-374

F. Wielandt, 'Badische Münz- und Geldgeschichte', 1979, Braun, Karlsruhe, 1979 ( 1955) p. 507 